\title{
Oil palm companies, privatization and social dissonance: towards a socially viable and ecologically sustainable land reform in Tanah Laut Regency, South Kalimantan, Indonesia
}

\author{
Astrid Meilasari-Sugiana ${ }^{1}$ \\ Universitas Bakrie, Indonesia
}

\begin{abstract}
This article argues that repossession of land by community members and land reform is vital to support the rural poor and to ensure the sustainability of the commons. Repossession requires bottom-up initiatives, social mobilization and external interventions. The case is a study of oil palm plantations in Tanah Laut Regency, South Kalimantan, Indonesia. The mangroves and lowlands in Tabanio and Ujung Batu have always been governed by indigenous (adat) laws. Through local government consent and partnership, in 2007 an oil palm plantation company under the Kintap Jaya Watindo (KJW) holding group obtained the right to privatize and convert \pm 900 hectares of lowland into plantations, resulting in ecological devastation and a loss of livelihood. This land grab led to conflicts with community members due to deception, unfavorable incorporation of community members into their schemes, unwanted land conversion and horizontal conflicts between communities. Increased commercialization of local oil palm resources, monetary compensation, and construction of basic infrastructure such as roads and latrines led to spiraling conflicts. Intimidation by local government officials and elites worsened conflict and in 2011 community members burned the plantation, leading to the company's withdrawal. Subsequently, social institutions and local rules have played a role in protecting coastal resources on behalf of the community, recognizing collective identity and social and ecological responsibilities. Behavioral change and innovative power structures are locally sensitive and environmentally appropriate.
\end{abstract}

Key Words: land grabbing, land reform, agricultural differentiation, extractive institution, exclusion, adverse incorporation, inclusion, power, common law

\section{Résumé}

Cet article affirme que la réappropriation des terres de la communauté par la réforme agraire est essentielle pour soutenir les ruraux pauvres et assurer la durabilité des ressources communes. La reprise de possession nécessite des initiatives partant de la base, une mobilisation sociale et des interventions externes. Le cas est une étude de plantations de palmiers à huile dans la régence de Tanah Laut, Kalimantan du Sud, en Indonésie. Les mangroves et les basses terres de Tabanio et Ujung Batu ont toujours été régies par des lois autochtones (adat). Avec l'accord et le partenariat des autorités locales, une société de plantation de palmiers à huile appartenant au groupe de contrôle de Kintap Jaya Watindo (KJW) a obtenu en 2007 le droit de convertir environ 900 hectares de basses terres en plantations, entraînant des dégâts écologiques et une perte de moyens de subsistance. Cet accaparement de terres a entraîné des conflits avec les membres de la communauté en raison de tromperie, d'incorporation défavorable des membres de la communauté dans leurs projets, de la conversion de terres non désirées et de conflits horizontaux entre les communautés. Le conflit a pris de l'ampleur avec la commercialisation croissante de l'huile de palme locale, des compensations monétaires et la construction d'infrastructures de base telles que des routes et des latrines. En 2011, des membres de la communauté ont brûlé la plantation, entraînant le retrait de l'entreprise. Par la suite, les institutions sociales et les règles locales ont joué un rôle dans la protection des ressources côtières au nom de la communauté, en reconnaissant l'identité collective et les responsabilités sociales et écologiques. Les changements de comportement et les structures de pouvoir innovantes sont sensibles à l'environnement local et adaptés à l'environnement.

\footnotetext{
${ }^{1}$ Dr. Astrid Meilasari-Sugiana, Lecturer in International Relations, Universitas Bakrie, Indonesia. Email: astrid.sugiana "at" bakrie.ac.id. Thankyou to the reviewers, and Prof. Simon Batterbury for his kindness and support. I would also like to thank the Indonesian Ministry of Research and Higher Education and Universitas Bakrie for funding this research.
} 
Mots clés: accaparement des terres, réforme agraire, différenciation agricole, institution extractive, exclusion, incorporation défavorable, inclusion, pouvoir, common law

\section{Resumen}

Este artículo propone que la recuperación de la tierra por parte de los miembros de la comunidad, así como la reforma agraria, son vitales para sostener a la población rural en pobreza y asegurar la sostenibilidad de los bienes comunes. La recuperación requiere iniciativas de abajo hacia arriba, movilización social e intervenciones externas. El caso es un estudio de las plantaciones de palma aceitera en la regencia de Tanah Laut, en Kalimantan del sur, Indonesia. Los manglares y las tierras bajas en Tabanio y Ujung Batu, siempre han sido gobernadas por leyes indígenas (adat). A través del consentimiento y la cooperación, en 2007 una compañía de plantación de palma aceitera del grupo Kintap Jaya Watindo (KJW) obtuvo el derecho de privatizar y convertir +900 hectáreas de tierras bajas en plantaciones, lo que produjo destrucción ambiental y la pérdida de medios de subsistencia. El acaparamiento de estas tierras provocó conflictos con miembros de la comunidad a causa del engaño, su injusta incorporación a sus esquemas, conversión indeseada de la tierra y conflictos entre comunidades. El incremento en la comercialización de recursos locales de palma aceitera, la compensación monetaria, y la construcción de infraestructura básica como caminos y letrinas, hizo escalar los conflictos. La intimidación por parte de funcionarios y élites locales empeoraron el conflicto y para 2010, miembros de la comunidad quemaron la plantación, lo que provocó el retiro de la compañía. Desde entonces, instituciones sociales y normas locales han tenido el papel de protectores de recursos costeros en favor de la comunidad, reorganizando la identidad colectiva, así como las responsabilidades sociales y ecológicas. El cambio en la conducta y las innovadoras estructuras de poder son localmente sensibles y ambientalmente apropiadas.

Palabras clave: Acaparamiento de tierra, reforma agraria, diferenciación agrícola, institución extractiva, exclusión, incorporación adversa, inclusión, poder, ley común

\section{Introduction}

Indonesia's population reached 210 million in 2000, with a growth rate of $1.8 \%$ per annum. Approximately 41 million people, or $22 \%$ of the population, live in or near coastal areas (BPS 2000: 5). Half of these are dependent on local coastal resources for their livelihood. The coastal areas provide employment and income for about 16 million people or $24 \%$ of the national labor force (Bappeda-Sulsel 1998: 11). The impacts of development activities on the country's ecosystems present a major challenge for policy makers, and are pervasive and intense. Land clearing, dredging and site preparation in the coastal watershed can lead to soil erosion and sedimentation (El Swaify 1983). Sediment accumulation leads to the formation of a shallower basin, and has adverse effects on water quality, circulation and the general ecosystem function (El Swaify 1983). The high productivity of lowland, marshes and mangroves make them attractive for oil palm plantations, providing Indonesia with a total of US $\$ 18$ billion or $11 \%$ of national exports in 2012, ranking third after coal and petroleum (Cramb 2018: 30). Oil palm plantations now cover about 10 million hectares or some 5 percent of the nation's land area, with growth predicted, affecting community gardens and forests (Cramb 2018: 32). ${ }^{2}$ Oil palm monoculture has serious effect on livelihoods and landscapes. While local communities hope for sustainable economic development, conflicts and contentions are more normal.

It is important, therefore, to discern how oil palm monoculture has created barriers and opportunities for community user groups to create adaptive social structures and cohesive political processes. "While agricultural intensification and integration into global markets may heighten profits and productivity for some" (McCarthy 2018: 115), and in the case of Tabanio village and Ujung Batu village in Tanah Laut Regency, South Kalimantan "such changes may squeeze many off the land, creating wealth for some by generating and perpetuating poverty for others" (McCarthy 2018: 115). This article focuses on the contentions and conflicts associated with oil palm expansion in Tabanio and Ujung Batu, as well as focusing on community efforts to protect the land and local livelihoods. I transcend the dichotomy of an oil palm-driven economy versus exploitation and marginalization of communities, highlighting that the trajectories of change associated with oil palm development are highly

\footnotetext{
${ }^{2}$ Lowland areas planted with oil palm amounted to 12 million hectares in 2013 (and only 1.7 million hectares in 1993)
} (Cramb 2018: 31). 
variable. Seeking to understand what drives agrarian change over time, the article discusses the way localized livelihoods and sustainable development are enabled or constrained by social, economic and political relations. The case study sites in Tabanio and Ujung Batu were chosen due to the presence of active communities that led to the repossession of communal land governed by adat customary law, and the emergence of social and political structures that were socially viable and ecologically sustainable.

\section{Natural resource governance in contemporary Indonesia: lessons from Tanah Laut Regency}

Natural resource governance during the Suharto era shifted from indigenous management to public and private management (Lynch and Harwell 2002). With public management, access to natural resources is held in trust by the state, whereas in private management tradable rights to natural resources are owned by an individual or company. The above shift was both culturally and politically engrained. First, the government's notions of economic growth and social welfare were equivalent to imparting private property rights for tradable purposes. This was carried out to promote investment, stimulate trade and achieve the trickle-down effect (Lynch and Harwell 2002). Second, as stipulated in Agrarian Law No 5/1960, Ministerial Decree No 5/1990 and the 19942020 National Environmental Management Strategy, in the interest of national integration and public welfare, decision making concerning access to and allocation of natural resources lies in the hands of the (national) government. Lynch and Harwell (2002) noted that Law No 5/1979 on village governance had three important consequences which reverberated into the current post-Suharto era. First, the diverse indigenous groups within Indonesia's archipelago were known and classified solely by social and economic indicators (e.g. race, occupation, income) as opposed to cultural and political indicators (e.g. identity, customs, sense-making, power relations). Second, the enactment of Law No 5/1979 transformed Indonesia's villages into mere administration units whilst disregarding their cultural and political significance. Third, the implementation of Law No 5/1979 did not provide community members with the right to manage the use, allocation and distribution of natural resources at the local level. Suharto's patrimony led to the assumption that the state, government officials and business community held the key for facilitating new initiatives and development within local communities (Bebbington 2006). During the post Suharto era, the Government of Indonesia adopted two policies with profound impacts on natural resource use, allocation and distribution: the policy for a decentralized public administration system (Thorburn 2001) and a policy for community based natural resource governance. There is the need to promote inclusive governance that is responsive to the needs and demands of local government and community user groups. The national government now perceives regional autonomy, decentralization and community based natural resource governance as the trajectory to achieving national integration and enduring sustainability.

Nonetheless, decentralization also opens up new challenges and issues that require going beyond the use of institutionalization and regulatory measures and into the social and political dimensions of natural resource governance, agricultural development and oil palm monoculture. In the context of oil palm, higher level politicians and economic agents have increasingly reached down to involve themselves in the provincial and district legal and institutional apparatus, shaping agricultural development and natural resource management outcomes in myriad and complex ways. Decentralization, and the Regional Governance Law No 23/2014 on the reassertion of the provincial government in providing authorization in forest and coastal resource use, as well as the effects of the 2007-2008 global financial crisis have led to the disengagement of the national government from controlling agricultural development in oil palm. This is marked by the removal of national government subsidies and services which previously supported smallholders and, with endorsement from the provincial government, by the shift away from smallholders to investor-managed agribusinesses and their intensification of control over land use and the commodity value chains in oil palm at the provincial level (Cramb 2018: 6). In Tanah Laut Regency where Tabanio and Ujung Batu villages are located, the oil palm plantation holding, Kintap Jaya Watindo, provides financial support and offers commissionaire positions to key departmental officials at the provincial, Regency and district levels, as well as granting funding to support them on influential 
parliamentary committees at the provincial level in South Kalimantan. Hence, provincial and Regency capacities in particular institutions and agencies are tied to specific policy goals involving oil palm expansion.

Tabanio and Ujung Batu villages contain two models for oil palm production found in Indonesia. There are (i) a nucleus estate and smallholder scheme, and (ii) an independent smallholder scheme. The first is characterized by the presence of a privately owned plantation company that acts as the nucleus, and the symbiotic presence of smallholders - local customary landholders including elites at the village and/or district level - and the village officials, who own small parcels of land. The nucleus provides the mill and other infrastructure for the 'plasma' smallholders, but they often sell their produce to the nucleus at far below the market price. The nucleus had land use rights for $70 \%$ of the 'vacant' coastal land in Tabanio and Ujung Batu, whereas the plasma smallholders cultivated $7 \%$ of the 'vacant' coastal land in each of the two villages. A small cooperative in both communities deals directly with the nucleus plantation company and sometimes provides mentoring, loans and credit to farmers for purchasing capital, thus leading to dependency and patronage. Relying on verbal agreements, farmers often complained that the burden of the credit was unclear and they suspected the loan should have been paid off long ago. Self-managed and self-funded smallholders sometimes receive short term loans for purchasing inputs such as capital, seeds, fertilizers, pesticides and for building market networks. They are unable to afford technical inputs in a consistent and timely manner.

Oil palm is a rich farmer's commodity, meaning that barriers to entry prevail from the time of inception to the time of harvest and commodity trading at the hands of wholesalers and retailers. Hence, different actors respond to these opportunities and constraints in distinct ways, leading to disparity and agrarian differentiation in agricultural development and coastal resource governance at the local level (McCarthy 2018: 113). "Thus, farmers engage with oil palm [and with processes in coastal resource governance] under distinctly different terms and through different processes with each of these modes of coordinating agriculture" (McCarthy 2018: 114). Hence, the narrative for equitable and sustainable governance of coastal resources is intercepted and mediated by those capable of transcending the participation gap and agrarian differentiation in agricultural development. In the case of Tabanio and Ujung Batu, for a certain period of time this led to the capture of the equitable and sustainable governance narrative by the narrow agricultural development discourse outlined in policy directives and corporate objectives. McCarthy (2018: 115) noted the following:

Farmer inclusion in the boom is mediated through smallholder schemes. As the scheme rolls out, farmers face the workings of cooperatives and village level processes including those affecting the division and allocation of scheme lands and contractual production and credit relations with the plantation core... [This] effects the conditions under which participants benefit together with the particularities of how this process pans out in each case, determines who remains enrolled in the scheme, who sells up their scheme entitlements, and who becomes a provider of cheap labor. In the second process, when farmers develop oil palm plots independently and market their fruit directly to free standing buyers and mills, they face the difficulty of obtaining access to capital, planting materials, fertilizers, and marketing networks without outside tutelage. Those unable to access the assets enter the oil palm production on favorable terms through the scheme or the market, are included on adverse terms, remain as low productivity farmers, are forced to sell up land, and/or forced to become casual wage laborers.

The depths and dimensions of participation in the local oil palm schemes determine access to decisionmaking power over coastal land use and governance. Equity and the sustainability of local coastal resources become secondary to the profit maximization goal of technocratic capitalist production in agricultural development. Equity and sustainability become the involuntary by-products of unfair agricultural production processes only insofar as community members mobilize through active and passive resistance to protect their social and ecological surroundings. Through unequal access to legal, institutional and financial resources, coastal 
populations have "different distributions of income and risk", leading to distinct trajectories of agrarian change, coastal land use patterns and coastal resource governance mechanisms (McCarthy 2018: 116).

Indonesia's neoliberal attitudes towards land and the surrender of land regulation to market mechanisms prioritize the productive, economic value of land over its societal and ecological values, which ultimately gives power over land use to those with the capital to exploit and commercialize it (Neilson 2016: 249). Contemporary agrarian resistance in response to land grabbing is passive and active, and the political agency of Indonesian farmers and farmer groups in demanding land reforms have significantly increased since the year 2000 (Neilson 2016: 261). There is discord between the farmer's discourse and conceptualization of land reform, and the dominant state-projected narrative of agricultural development and natural resource extraction found in mainstream land use policies (Neilson 2016: 261).

Differences in incomes and risks led to violent protests in 2011 by Tabanio community members, marked by looting and burning of the oil palm plantation. In early 2012 community members clamored for equity and declared that the local adat or customary law in Tabanio and Ujung Batu had been captured by government and the oil palm corporation, signifying that the adat body was simply an extension and handmaiden of government policies and corporate goals at the hands of elite village and government representatives. Through a referendum with the provincial government and the People's Representative Council in 2012, community members in Tabanio demanded the restructuring of the local adat body based on Constitutional Court Decision No 35/2012 that stipulated the rights of communities in reforming local institutions and legal constituents for the equitable governance of natural resources.

The history of oil palm in Tabanio and Ujung Batu suggest that although power and authority can influence community members, they are incapable of homogenizing and aggregating preferences through force and the disciplinary institutional network alone. Community members will always be conscious of how power influences and alters group and individual preferences. Moreover, this local case suggests that protecting the coastal environment clashes with other discourses, leading to power struggles and a sustained questioning of local power and authority in the face of inequity and ecological devastation. Because there are multiple sources of power, dynamic power struggles and constant legal and institutional reforms, it is not the case that local populations are 'excluded' or 'included' in oil palm development. This article "argues for the need to go beyond simplistic dualist model of exclusion and inclusion to grasp the simultaneous interaction of processes leading to the inclusion, exclusion and adverse incorporation" (McCarthy 2018: 116).

\section{Research methods}

A history of community participation and political activism in protecting the landscape against oil palm agricultural expansion activities in Tabanio and Ujung Batu made this an interesting case to explore. Data collection was conducted through participant observation, in-depth and biographical interviews, and the compilation of secondary data in relation to government policies, programs and projects in South Kalimantan. I began by observing natural resource management practices and noted the issues and contentions which surfaced, in 2013 and early 2014, obtaining rudimentary data on the topography of the site and the agricultural development and natural resource governance schemes. These inquiries and discussions revealed the dynamics and complexities associated with inclusion/exclusion in agricultural development and sustainable land and coastal resource governance. The main fieldwork took place at times between December 2014 and November 2015.

An ethnographic approach helped to reveal the "rules" for constructing social reality, assuming multiple perspectives and the presence of multiple and incomplete subjectively-derived realities. Twenty-seven informants were selected through purposive sampling. Individuals from various groups and backgrounds were interviewed, chosen according to the environmental issues present within the locality, the extent of the research subjects' involvement in coastal resource governance, and the effects of policies, programs and projects (Table 1). Adequate representation of community user groups was important. Secondary data was obtained directly from government departments, private corporations, NGOs, government consultants and academics through private meetings, and indirectly through internet publications and university and private libraries. 
The following analytical sequences were used for analyzing and assessing every narrative and/or text contained within the primary data (Fetterman 1989; Neuwman 2003). First, the interview transcripts and fieldnotes were coded. Next, data and contexts across interviews were compared to accentuate and explain the specific and unique. The illustrative method was then applied to determine the core categories and their subdimensions and to integrate ideas into hypotheses between core categories.

\begin{tabular}{|c|c|c|c|}
\hline Research informants & Reasons & Research informants & Reasons \\
\hline $\begin{array}{l}\text { Kintap Jaya Watido, Ltd. } \\
\text { representatives } \\
\text { ( } 2 \text { informants) }\end{array}$ & $\begin{array}{l}\text { Aid government officials in } \\
\text { facilitating conflict resolution among } \\
\text { community members and the } \\
\text { corporation. }\end{array}$ & $\begin{array}{l}\text { Village officials } \\
\text { (2 informants) }\end{array}$ & $\begin{array}{l}\text { At the forefront of promoting and } \\
\text { implementing new initiatives in } \\
\text { villages. }\end{array}$ \\
\hline $\begin{array}{l}\text { Researchers and } \\
\text { academicians } \\
\text { ( } 2 \text { informants) }\end{array}$ & $\begin{array}{l}\text { Aid the Regency planning board in } \\
\text { planning its annual land use and } \\
\text { coastal zone management programs } \\
\text { and projects. }\end{array}$ & $\begin{array}{l}\text { Community leaders } \\
\text { (5 informants) }\end{array}$ & $\begin{array}{l}\text { The status quo in Tabanio and Ujung } \\
\text { Batu who are respected and aspired } \\
\text { to by villagers. }\end{array}$ \\
\hline $\begin{array}{l}\text { Members of the House of } \\
\text { Representatives } \\
\text { (2 informants) }\end{array}$ & $\begin{array}{l}\text { Approves the selection and funding } \\
\text { of policies, programs and projects. } \\
\text { Approves investments within the } \\
\text { region. Aid in conflict resolution } \\
\text { processes. }\end{array}$ & $\begin{array}{l}\text { Laboring fishermen and farm } \\
\text { laborers. } \\
\text { ( } 5 \text { informants) }\end{array}$ & Marginalized community members. \\
\hline $\begin{array}{l}\text { District heads } \\
\text { ( } 2 \text { informants) }\end{array}$ & $\begin{array}{l}\text { The forefront personnel responsible } \\
\text { for resolving land disputes and } \\
\text { conflicts and managing projects } \\
\text { within the villages. }\end{array}$ & $\begin{array}{l}\text { Boat owners } \\
\text { (3 informants) }\end{array}$ & $\begin{array}{l}\text { Decision makers and owners of } \\
\text { boats who protested against KJW's } \\
\text { entrance into the village. }\end{array}$ \\
\hline $\begin{array}{l}\text { The Provincial planning } \\
\text { board and the Regency } \\
\text { provincial board } \\
\text { ( } 2 \text { informants) }\end{array}$ & $\begin{array}{l}\text { Coordinates land and coastal zone } \\
\text { development policies across the } \\
\text { regencies. }\end{array}$ & $\begin{array}{l}\text { The Regency marine and } \\
\text { fishery resource department } \\
\text { ( } 2 \text { informants) }\end{array}$ & $\begin{array}{l}\text { Plans, implements and funds land } \\
\text { use and land development projects } \\
\text { and fishery management projects. }\end{array}$ \\
\hline
\end{tabular}

Table 1: Research informants in South Kalimantan.

\section{Land in Tabanio and Ujung Batu}

Both communities are in Tanah Laut Regency, South Kalimantan Province (Figures 1 and 2). Tabanio is a coastal village in Takisung District and Ujung Batu village is inland in Pelaihari District. The districts contain around 30,000 people and Tabanio is the larger village with a population of 4,000 in 2015. Both villages have rolling hills in the north and west, flat and fertile land in the south and coastal areas to the southwest with major rivers and tributaries emptying into the Java Sea (Figure 2). The extensive lowland produces corn, beans, lentils, cassava and dry rice, as well as cash crops such as coconut, cashew, cocoa, cinnamon, coffee, rubber and palm oil. Farm animals commonly owned by villagers are, among others, cows, sheep, goats, buffalos, pigs and horses. A majority of the villagers (70\%) work as farmers and fisherfolk, and some did both according to the season. There is some aquaculture, but little tertiary sector work, mostly in the civil service and in private companies. The women in both villages aid their spouses in working the land, marketing their catch and tending to aquaculture. A majority of the fishers work for boat owners who resided in nearby villages, in a patron-client relationship. 
Some of the land in Tabanio and Ujung Batu was privatized and legally certified by local land agencies and notaries, and some was communally owned and managed. A percentage of the flat land was fallowed and overgrown by white samet (melaleuca cajuputi) trees, with some marsh and wild grasses, and coastal mangroves (i.e. rhizophoraceae). Uncultivated coastal land was governed by multiple management regimes. Village elders assumed common governance through indigenous laws guaranteeing equity and sustainability, government officials assumed public governance through policies and programs for local farming and sand mining, and villagers had user rights for sustenance and livelihood.

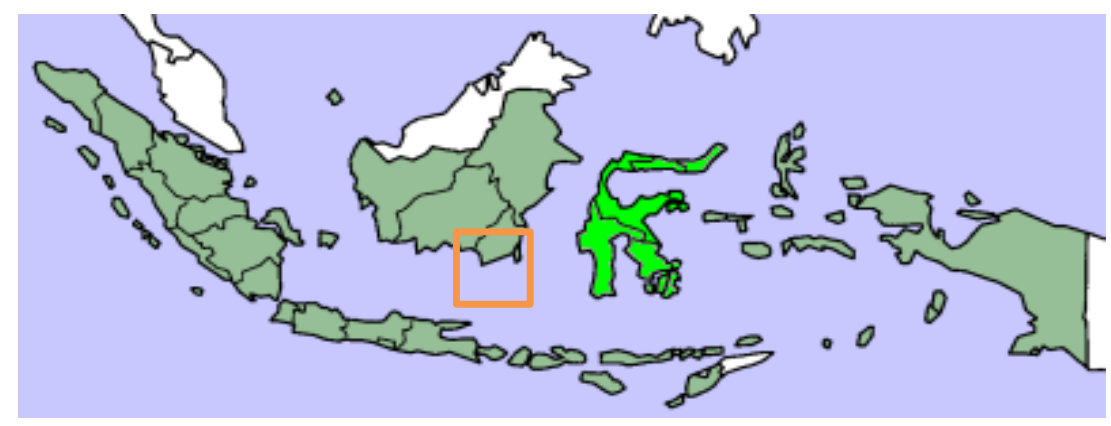

Figure 1: Study area, island of Kalimantan or Borneo, within the Indonesian archipelago. (USAID)

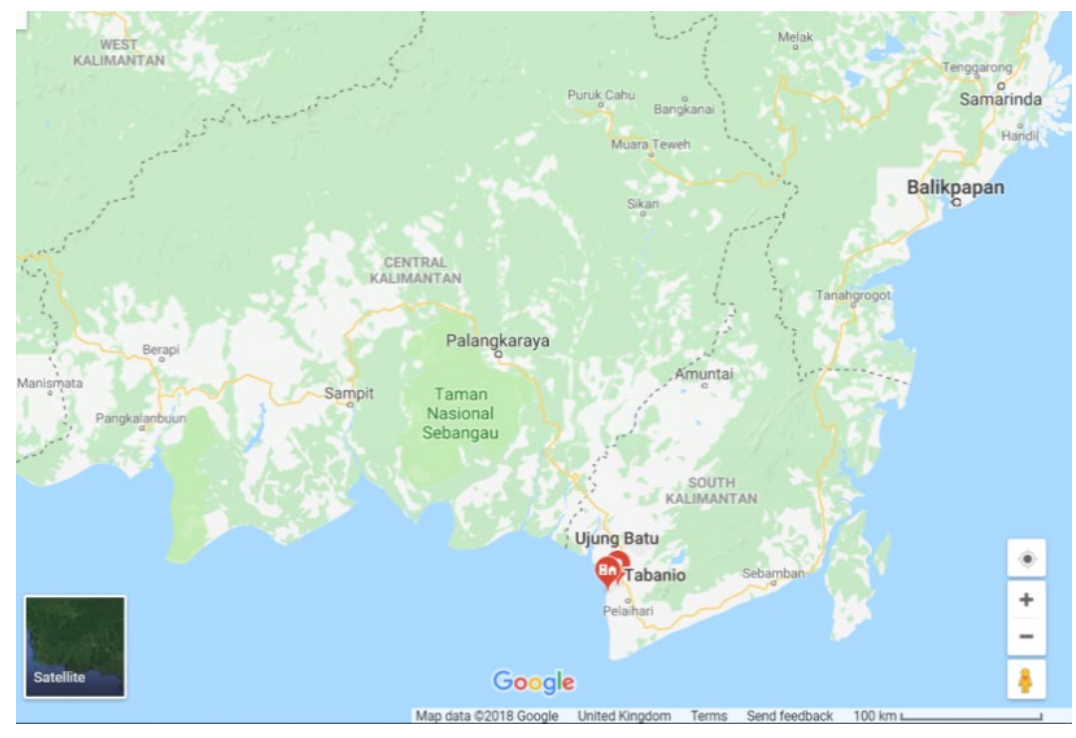

Figure 2: Tabanio Village and Ujung Batu Village, South Kalimantan. (Google)

The presence of lush and uncultivated land attracted plantation companies, especially palm oil plantation companies. Changes in the physical environment in turn led to changes in livelihood, lives and income in both villages. In May 2007, under the Nucleus Estate and Smallholder (NES) scheme, Kintap Jaya Watindo Ltd. sought to adopt and implement an 80:20 scheme for an initial ten year period, whereby community groups from Tabanio and Ujung Batu would provide $80 \%$ of the land to be planted with oil palm by the company and of which, $20 \%$ would be given for the community to manage. Villagers think this arrangement was forced through by deception and manipulation by local elites and corporate representatives, endorsed by the district and provincial government. Moreover, although a majority of the villagers in Ujung Batu affirmed and consented to 
the scheme, a majority in Tabanio believed it was not beneficial enough for them, and demanded a fairer landuse arrangement through negotiations with the company and the government. Initially community members in Tabanio agreed to the presence of Kintap Jaya in the village, but as the scheme rolled out, they refused the company's presence because:

(i) there had been no informed consent;

(ii) there was perceived manipulation, intimidation, force, corruption and duress leading to unfair and unsustainable land use acquisition by the holding group;

(iii) community members lost all access and user rights to the land entrusted to the holding group.

The district and village head was accused of receiving rent money, bribes and gifts from Kintap Jaya Watindo for single-handedly surrendering access and land use to the company. Some community groups in Tabanio are still waiting to receive their agreed share of the planted land promised to them by the district and village government. In this community, "...vested interests, patronage and corruption reinforce patterns of rentseeking and exploitative behavior which systematically work against the interests of small farmers" (Neilson 2016: 247). Moreover, a large majority of the plantation laborers hired by the holding in Tabanio and Ujung Batu were migrant laborers from outside the area. This eased the assurance of loyalty and subservience to the corporation. Villagers in Tabanio demanded the withdrawal of the oil palm corporation in 2009, in the absence of an agreement between the various parties over access and land use concessions. District and Regency government officials attempted to mediate land use conflicts apolitically by disbursing monetary compensation and constructing basic infrastructure including latrines and roads in both communities. One year later, no agreement had been reached and the conflict escalated. Land consolidation (i.e. the planned rearrangement of land parcels and their ownership by the National Land Agency for increased equitability and sustainability in land governance) can, in theory, be achieved by land users or be directly carried out by the National Land Agency through planned consolidations. Nonetheless, land consolidation in Tabanio proved extremely challenging since it required a high degree of cooperation from stakeholders asked to give up part of their land for the common good.

In Tabanio, the following emerged as a consequence of the discord:

(i) resistance by farmers to unjust land acquisition

(ii) class-based land redistribution

(iii) a campaign to recognize adat claims through Constitutional Court Decision 35/2012

(iv) negotiated land access rights in which the oil palm corporation was afforded access on a temporary and restricted basis, and

(v) a critique of the agricultural corporate regime and the capitalist mode of production and land use pattern.

Hence, although the need for individuals to act as a collective can be serendipitous, it can also be purposeful, as in Tabanio's effort to protect and conserve its land and coastal resources. I found that individuals self-organize themselves to achieve development, and to instill order and social cohesion.

\section{The Tabanio conflict}

Oil palm is a major source of income and wealth for farmers, companies and the Indonesian state. It is more profitable than rattan, rubber and vegetable oil (Levang et al. 2018: 284), but it requires less labor per unit of land (Li 2018: 354). Although oil palm plantations require substantial investment and capital to start, oil palm provides high returns to the agro-industrial sector and easily attracts foreign capital to the country. On a different note, community groups also long to have a regular source of income to secure their health, education and welfare 
and to purchase land, housing and vehicles. Campaigns by NGOs have shown how vulnerable indigenous communities have lost their customary forests with their livelihoods to large-scale oil palm plantation companies. The press regularly relays concerns of non-governmental organizations regarding the negative impacts of palm oil development (Levang et al. 2018: 284).

It is unfounded to assume that community members utterly reject the presence of oil palm plantations due to the pervasiveness of conflicts. I argue that such claims are incorrect and contradict the desires of local farmers to acquire stable income and improved welfare through the socially viable and ecologically sustainable practices of oil palm agricultural development. "The likelihood of inclusion/exclusion or adverse incorporation depends on the terms under which smallholders engage with oil palm: how oil palm is introduced, how it is taken up and how local institutional contexts and social relations shape the way subsequent changes play out" (Levang et al. 2018: 285). The constraints and enablers for altering the above constituents and for participating in decision making towards equitable and sustainable land use depend on the social and political activism of the various power bases along with the pace, intensity and frequency of efforts at mobilization. The need to involve higherlevel authorities (i.e. the provincial government and the People's Representative Council) to enable changes in the power, capital and institutional-legal structure depends on the risks and urgencies perceived by the various groups and power bases. This section and the next portray the contentions and conflicts associated with oil palm expansion in Tabanio and Ujung Batu and highlight emerging spaces and trajectories for equity and sustainability through social mobilization, political activism and land repossession by community user groups.

\section{Environmental pollution and impacts on agricultural livelihoods}

The presence of Kintap Jaya Watindo, Ltd. in Tabanio altered the natural and social landscapes within the village. In the five year period from 2007 until 2011, more than 1,300 ha was converted into palm oil plantations. The environmental impacts are numerous, including the draining and conversion of Tabanio's marsh, estuaries and wetlands into dry land for palm oil, loss of biodiversity, drainage of peatlands, soil pollution, pesticide and herbicide runoff, contamination of local rivers, soil erosion and wastewater dumping.

Tabanio's farmland was adjacent to its marsh and estuaries, and here farmers grew rice, beans, lentils and corn. Water from the marsh and estuaries was utilized to irrigate the rice fields by way of channels and tunnels devised by villagers. These were manually opened and closed to adjust the flow and volume of water, thus acting as irrigation canals in dry periods. During the rainy season, water overflowing from the marsh and estuary was diverted into the rivers and streams that passed through the rice fields and agricultural land. Kintap Jaya Watindo, with the approval of the Regency government and village elites, drained and converted Tabanio's wetlands by constructing dams and dikes to direct water into the catchments. This destabilized the agro-hydrological system, and nutrient-rich water for irrigating farmlands and rice fields was lost. Runoff increased from agricultural land. Coupled with Indonesia's dry season and the loss of irrigation, Tabanio's rice fields and farmlands became dry and crop failure was frequent. This led to decreasing income for local farmers and merchants. The company also cleared lowlands for palm oil. The white samet trunks and wood were collected by villagers and sold for construction, firewood and boatbuilding, but there was no sustainable regrowth. Social stratifications became evident in access to remaining natural resources, decision-making powers, and access to the privileges allocated by the government and the company. Table 2 below explains the contentions and conflicts between Kintap Jaya Watindo, the citizens of Tabanio village and the Regency, district and village governments.

\section{Rejection of companies and unwanted land conversion}

Kintap Jaya Watindo is a well-known oil palm company in South Kalimantan. Prior to entering Tabanio

and Ujung Batu, it initiated its production in Kintap District, Tanah Laut Regency. The holding in Kintap District was 6,137 hectares, with 5,373 ha used for production. The operations in Tabanio and Ujung Batu were forecast to produce around 73,770 tons of crude oil palm per year (45 tons per hour). In accordance with the requirement for sustainable oil palm plantation set by Indonesia's Minister of Agriculture through Regulation No. 
19/Permentan/OT.140/3/2011, Kintap Jaya Watindo received the Indonesian Sustainable Palm Oil (ISPO) Certificate in 2011. The holding also received ISO 9001: 2008 and ISO 14000: 2004 certificates, and the Indonesian Ecolabel Company also awarded the corporation a Sustainable Plantation Management certificate. Nonetheless, these certificates did not guarantee sustainable practices in Tabanio and Ujung Batu as evidenced later in the article.

The demand for oil palm, coupled with its price, led to the demand to open new land for its cultivation and production. It was the presence of fertile and uncultivated land in Tabanio and Ujung Batu that first attracted the company. Under national law, palm oil companies are obliged to obtain the consent of land users, including farmers and communities without registered title, before taking over their lands for plantation development. In 2004 Kintap Jaya entered Ujung Batu and a majority of the population supported the company's presence at that time. Kintap Jaya Watindo also approached the provincial, Regency and district governments to obtain permits for working Tabanio's coastal land. In 2007, contentions and oppositions emerged in Tabanio with a majority of the population refusing to cede their land for use by the plantation. Through the local government and village head, in May 2007 the holding obtained a permit to work the uncultivated coastal land and activities began in 2008. Informed consent was never given, and community user groups were hardly aware that they would have to cede all user rights to the land subsequent to Kintap Jaya's entry. So, the company land release was not consensual and not done through collective decision making. Community groups complained that they were not informed that they would lose their land rights. As explained above, consent was never granted by a large majority of the villagers, and duress, manipulation and intimidation by officials and village elites were rampant.

On the other hand, company managers claimed that communities also know how to take advantage of unclear tenure in order to pressure companies for compensation. In the five year period from 2007-2011 during Kintap Jaya's presence in Tabanio, no agreement was ever reached between the company and Tabanio's community groups. In 2010 when community members protested and demanded that the land be returned to Tabanio, the government reaffirmed and reinstated the borderlines between Tabanio and Ujung Batu through Regency Decree No 179/2010, leading to a loss of land on the part of Tabanio due to Tabanio's rejection of Kintap Jaya and Tabanio's refusal to compromise with the government and the plantation company. This infuriated community members who felt dispossessed and alienated due to conflicting views about control over land. Table 2 highlights the contentions and conflicts associated with land use conflicts in Tabanio. Levang et al. (2018: 287) noted the following with regard to the above:

The land rights of local land users are unclear and seldom formally identified. In these cases, the people reject the proposed plantation system as opposed to the oil palm as such. People are repudiating a system that is externally imposed without any means of public participation...These changing relations are shaped by the appearance or absence of smallholder development schemes; their design and how they rolled out, including the role the state plays at critical points in the degree of villager control over village institutions and processes; the way individuals take up oil palm in an already differentiated agrarian landscape and how this works with or against existing livelihood practices and village structures; how the spatial situation and structural advantages or disadvantages of villagers affect their ability to respond; and the workings of land tenure systems and informal land markets.

Rumors circulated in Tabanio that the compensation paid to farmers for relinquishing their land was less than US\$50 per hectare and that the money was entrusted to the village government whose transparency and accountability to local community user groups was poor. The Regency government was accused of masterminding the scheme and intimidating the villagers, whereas the village and district head were accused of manipulation and fraud, resulting in vandalism and destruction of property belonging to the village and district head, and physical abuse towards the village head. The conflict proved incapable of being resolved at the village, district and even Regency levels. In the case of Tabanio, community user groups demonstrated and rioted in front 
of the Provincial House of Representatives in 2010 to demand the repossession of stolen land and the restoration of Tabanio's coastal areas. In the face of mass protests and demonstrations, South Kalimantan's government officials and Kintap Jaya compelled community user groups to cease protest and accept compensation, as follows:

(i) a buffer and dike to prevent seawater infiltration and inundation,

(ii) a donation of US $\$ 30,000$ to rebuild local mosque, and

(iii) compensation of US\$16,000.

Reinstating community control over land use to achieve equity and sustainability was never even proposed by the government or the Provincial House of Representatives. The social, ecological and livelihood costs associated with oil palm expansion in Tabanio greatly outweighed the compensation offered. As well, villagers felt undermined, betrayed and detected deception by the holding group when they failed to witness

(i) a signed Memorandum of Understanding between the relevant parties,

(ii) the gradual disbursement of compensation money, and

(iii) the promised construction of buffers, dikes and local mosques.

In December 2010 there was further violence when community members in Tabanio destroyed houses, smashed cars and stole produce belonging to the holding group. The police, the local security forces and the provincial task forces arrived to enforce security and order. Community members were arrested and charged. Local villagers perceived this as the undeserving criminalization of local people, and government officials continued to protect the interests of the oil palm company that continued its production and expansion in Tabanio and the District. Community disillusionment and anger continued, culminating in burning the oil palm plantation headquarters along with a number of houses, possessions and land belonging to village and district officials in May 2011. Indonesia's armed forces came to secure order in Tabanio shortly afterwards.

The enduring resistance in Tabanio caught the attention of South Kalimantan's Governor and head of the Provincial House of Representatives, and in June and July 2011 mediation took place in the governor's office. Attended by members of the House of Representatives, judges from the provincial court, the governor of South Kalimantan, government officials from Tanah Laut Regency and Tabanio village and community members in Tabanio, the negotiations led to the formulation and stipulation of MoUs and judicial doctrines which mandated the termination of Kintap Jaya Watindo's activities in Tabanio. The reason was the protection Tabanio's coastal environment. In August 2011 Kintap Jaya Watindo terminated its operations in Tabanio and withdrew. The land previously managed by the agro-plantation company was then returned to the village and is now collectively managed as common property. Community members regained access and user rights to the land and coastal resources and adat laws are now applied.

\section{Deception and horizontal conflicts}

Community groups in Tabanio were poorly informed and were lured into believing that oil palm can grow with little maintenance, giving high financial high returns. Kintap Jaya initially carried out face-to-face meetings with community groups to convince village representatives to surrender their land, with government intermediaries. During these meetings officials and company representatives often made promises to develop roads, schools, clinics and employment, citing the high prices that palm could reach, and the wealth that landowners could gain from it. Companies often fail to meet these promises. "The informality of promises made by company representatives, often in a face to face manner without written documentation, complicates the issue of agreements as they cannot be definitively substantiated" (Levang et al. 2018: 288). Horizontal conflicts occurred between communities, namely between residents of Tabanio and residents of Ujung Batu. Differing 
attitudes towards the company and unequal distribution of benefits triggered intra-community conflicts between these villages. Local elites and village officials in Ujung Batu were rumored to have received money to pressure villagers to accept the company's offer, and that this money was disbursed and delivered to locals in Ujung Batu. These horizontal conflicts were neither resolved through customary laws, nor were they documented. In other instances, it was rumored that locals in Ujung Batu were allowed to harvest palms owned by the company to avoid conflicts when their own oil palm plots did not provide sufficient yield to support their daily needs. Housing for the laborers in Ujung Batu were another issue. These were small in size. Li (2018: 358) observed elsewhere, on plantations in Sumatra, that "the laborers would be settled as family units, and given access to tiny plots of land just sufficient to cheapen the costs of the wages, but not big or secure enough to draw labor away from the plantation." She also notes that "their settlements had a superficial resemblance to peasant villages, but their function was that of a labor reserve, from which the plantation could draw as needed, but for which they took no responsibility" (2018: 359).

As well, in early November 2010 community user groups in Tabanio claimed that the 2007 borderline between Tabanio and Ujung Batu that was informally drawn by officials and single-handedly reinstated in July 2010 through Regency Decree No 179/2010 was done without informed consent. Ujung Batu was entitled to more land because of it. Tabanio residents demanded that the borderline be shifted and that the residents of Tabanio be awarded more land due to (i) the land grab by Kintap Jaya, and (ii) an unfair enactment of Regency Decree No 179/2010. This dispute between Tabanio and Ujung Batu was 'resolved' by government officials and the holding group by undermining community groups in Tabanio and, through Regency Decree No 130/1253 made in late November 2010, by reinstating the borderline between Tabanio and Ujung Batu as drawn in July 2010 (Regency Decree No 179/2010). This means nothing changed, and the dispute remains unresolved. Another disparity was that residents of Ujung Batu were given access to the capital and resources owned by the holding (e.g. mill, equipment, knowledge, credit, 'unsuitable'/infertile farming land, etc.) for 'joint venture' purposes, whereas residents of Tabanio were not allowed any of these. This was because Ujung Batu willingly relinquished land to the government and the company and took compensation, unlike Tabanio where deception was used and relations quickly soured. Commercial actions and top-down regulatory measures exacerbated intra-community conflicts. 


\begin{tabular}{|c|c|c|c|c|c|c|c|c|c|c|c|}
\hline 1992 & May 2007 & 2009 & $\begin{array}{c}\text { February } \\
2010\end{array}$ & July 2010 & $\begin{array}{c}\text { October } \\
2010\end{array}$ & $\begin{array}{c}\text { November } \\
2010\end{array}$ & $\begin{array}{c}\text { December } \\
2010\end{array}$ & May 2011 & June 2011 & July 2011 & August 2011 \\
\hline $\begin{array}{l}\text { (1) Initial } \\
\text { boundary } \\
\text { drawn } \\
\text { around the } \\
\text { areas } \\
\text { intended for } \\
\text { Kintap Jaya } \\
\text { Watindo } \\
\text { Ltd. and (2) } \\
\text { Initial } \\
\text { boundary } \\
\text { drawn } \\
\text { demarcating } \\
\text { the village of } \\
\text { Tabanio and } \\
\text { the village of } \\
\text { Ujung Batu. }\end{array}$ & $\begin{array}{l}\text { Land } \\
\text { surrendered } \\
\text { by village } \\
\text { head and } \\
\text { Regency } \\
\text { govt. to } \\
\text { Kintap Jaya } \\
\text { Watindo } \\
\text { Ltd. }\end{array}$ & $\begin{array}{l}\text { Written } \\
\text { acknowledge } \\
\text { ment from } \\
\text { Tabanio } \\
\text { village head } \\
\text { stating that } \\
\text { Tabanio } \\
\text { village will } \\
\text { not surrender } \\
\text { its land to } \\
\text { Kintap Jaya } \\
\text { Watindo } \\
\text { Ltd. Tabanio } \\
\text { villagers } \\
\text { refused to } \\
\text { collaborate } \\
\text { with KJW. }\end{array}$ & $\begin{array}{l}\text { Village and } \\
\text { Regency meeting } \\
\text { in Tabanio to } \\
\text { discuss the } \\
\text { redrawing of the } \\
\text { boundary } \\
\text { between Tabanio } \\
\text { and Ujung Batu, } \\
\text { discussing the } \\
\text { exit of KJW. } \\
\text { from Tabanio } \\
\text { village, and the } \\
\text { returning of land } \\
\text { to communities } \\
\text { in Tabanio. }\end{array}$ & $\begin{array}{l}\text { Regency Decree No. } \\
179 \text { states that } \\
\text { boundary between } \\
\text { Tabanio and Ujung } \\
\text { Batu villages will be } \\
\text { redrawn. Tabanio } \\
\text { lost land after } \\
\text { refusing to } \\
\text { collaborate with } \\
\text { KJW. The land is } \\
\text { allocated to Ujung } \\
\text { Batu village instead } \\
\text { because Ujung Batu } \\
\text { is willing to work } \\
\text { with KJW. Decree is } \\
\text { signed by the } \\
\text { Regency Head in } \\
\text { Tanah Laut } \\
\text { Regency. }\end{array}$ & $\begin{array}{l}\text { Big } \\
\text { demonstrations } \\
\text { and riots } \\
\text { occurred in } \\
\text { front of the } \\
\text { House of } \\
\text { Representatives } \\
\text { at the } \\
\text { Provincial and } \\
\text { the Regency } \\
\text { Level with the } \\
\text { Governor and } \\
\text { Regency Head } \\
\text { getting } \\
\text { involved to } \\
\text { resolve the } \\
\text { conflicts. }\end{array}$ & $\begin{array}{l}\text { Promulgation } \\
\text { of Regency } \\
\text { Decree No. } \\
130 / 1253 \text { by } \\
\text { the Regency } \\
\text { head to } \\
\text { reinstate the } \\
\text { boundaries in } \\
\text { Regency } \\
\text { Decree No. } \\
179 \text { and to } \\
\text { ensure the } \\
\text { continuation of } \\
\text { the activities } \\
\text { of KJW. in } \\
\text { previously } \\
\text { utilized areas } \\
\text { in Tanah Laut } \\
\text { despite } \\
\text { objections } \\
\text { from } \\
\text { communities } \\
\text { in Tabanio. }\end{array}$ & $\begin{array}{l}\text { A major } \\
\text { conflict and } \\
\text { destruction of } \\
\text { property } \\
\text { occurred in } \\
\text { Tabanio } \\
\text { Village, } \\
\text { Pelaihari } \\
\text { District. } \\
\text { Community } \\
\text { members } \\
\text { enacted a } \\
\text { 'social } \\
\text { revolution' - six } \\
\text { houses were } \\
\text { destroyed and a } \\
\text { number of cars } \\
\text { smashed. }\end{array}$ & $\begin{array}{l}\text { The } \\
\text { destruction } \\
\text { and burning } \\
\text { of the } \\
\text { plantation } \\
\text { company by } \\
\text { villagers and } \\
\text { community } \\
\text { members in } \\
\text { Pelaihari } \\
\text { District. It } \\
\text { got the } \\
\text { attention of } \\
\text { the governor } \\
\text { of South } \\
\text { Sulawesi and } \\
\text { the Regency } \\
\text { head in } \\
\text { Tanah Laut } \\
\text { Regency. }\end{array}$ & $\begin{array}{l}\text { Mediation and } \\
\text { negotiations } \\
\text { held in the } \\
\text { governor's } \\
\text { office at the } \\
\text { provincial } \\
\text { level. Attended } \\
\text { by community } \\
\text { members, } \\
\text { members of the } \\
\text { House of } \\
\text { Representatives } \\
\text { at the } \\
\text { provincial and } \\
\text { Regency levels, } \\
\text { the governor of } \\
\text { South } \\
\text { Kalimantan, the } \\
\text { head of Tanah } \\
\text { Laut Regency } \\
\text { and local } \\
\text { government } \\
\text { heads. }\end{array}$ & $\begin{array}{l}\text { Meetings, } \\
\text { negotiations with } \\
\text { the governor, } \\
\text { Regency head, } \\
\text { district head, } \\
\text { government } \\
\text { officials and } \\
\text { representatives } \\
\text { from KJW, in } \\
\text { Tabanio. Senior } \\
\text { officials from the } \\
\text { police and the } \\
\text { military at the } \\
\text { provincial level } \\
\text { also came to } \\
\text { Tabanio. }\end{array}$ & $\begin{array}{l}\text { KJW terminated } \\
\text { its operations in } \\
\text { Tabanio village. } \\
\text { KJW withdrew } \\
\text { from Tabanio } \\
\text { although it was } \\
\text { still operating in } \\
\text { Ujung Batu. }\end{array}$ \\
\hline $\begin{array}{l}\text { Community } \\
\text { members are } \\
\text { aware and } \\
\text { anxious with } \\
\text { the entrance } \\
\text { and possible } \\
\text { expansion of } \\
\text { Kintap Jaya } \\
\text { Watindo. } \\
\text { Community } \\
\text { groups heard } \\
\text { it through } \\
\text { village and } \\
\text { Regency } \\
\text { officials. }\end{array}$ & $\begin{array}{l}\text { Complaints } \\
\text { and } \\
\text { uprisings } \\
\text { by } \\
\text { community } \\
\text { members. }\end{array}$ & $\begin{array}{l}\text { Community } \\
\text { members } \\
\text { held } \\
\text { meetings } \\
\text { with district } \\
\text { and Regenney } \\
\text { government } \\
\text { requesting } \\
\text { that some of } \\
\text { the land in } \\
\text { Tabanio be } \\
\text { returned to } \\
\text { the village } \\
\text { and the } \\
\text { people. }\end{array}$ & $\begin{array}{l}\text { Villagers in } \\
\text { Tabanio } \\
\text { demanded a } \\
\text { meeting with the } \\
\text { provincial } \\
\text { government. } \\
\text { Community } \\
\text { groups travelled } \\
\text { to the Regency } \\
\text { and provincial } \\
\text { government but } \\
\text { was treated } \\
\text { lightly in the } \\
\text { province and no } \\
\text { meeting took } \\
\text { place. }\end{array}$ & $\begin{array}{l}\text { Villagers and } \\
\text { community groups } \\
\text { in Tabanio are angry } \\
\text { because KJW Ltd. is } \\
\text { still operating at full } \\
\text { speed and no land is } \\
\text { returned to } \\
\text { community members } \\
\text { in Tabanio. } \\
\text { NGOs started } \\
\text { providing advocacy } \\
\text { but also fueled } \\
\text { contention and } \\
\text { conflict. }\end{array}$ & $\begin{array}{l}\text { Formation of } \\
\text { task force } \\
\text { groups at } \\
\text { Regency Level. } \\
\text { Task force } \\
\text { groups are } \\
\text { mediators } \\
\text { between } \\
\text { community } \\
\text { members in } \\
\text { Tabanio, KJW } \\
\text { and } \\
\text { government } \\
\text { departments to } \\
\text { foster } \\
\text { consensus on } \\
\text { land } \\
\text { use/ownership. }\end{array}$ & $\begin{array}{l}\text { Community } \\
\text { members in } \\
\text { Tabanio } \\
\text { village are } \\
\text { anxious and } \\
\text { demanded that } \\
\text { KJW: 1) Build } \\
\text { a sea wall to } \\
\text { prevent } \\
\text { seawater } \\
\text { infiltration, 2) } \\
\text { Donate US\$ } \\
\text { 30,000 to } \\
\text { rebuild the } \\
\text { mosque, 3) } \\
\text { give } \\
\text { compensation } \\
\text { of } \\
\text { US\$ 16,000. }\end{array}$ & $\begin{array}{l}\text { After the } \\
\text { village head in } \\
\text { Tabanio and } \\
\text { the district head } \\
\text { in Pelaihari } \\
\text { District were } \\
\text { physically } \\
\text { abused by } \\
\text { villagers, the } \\
\text { local security } \\
\text { forces and the } \\
\text { provincial task } \\
\text { forces arrived } \\
\text { to enforce } \\
\text { security in the } \\
\text { village/district. }\end{array}$ & $\begin{array}{l}\text { The armed } \\
\text { forces came } \\
\text { to secure } \\
\text { order. }\end{array}$ & $\begin{array}{l}\text { Community } \\
\text { members in } \\
\text { Tabanio village } \\
\text { submitted a list } \\
\text { of issues to be } \\
\text { agreed upon, } \\
\text { including the } \\
\text { termination of } \\
\text { KJW's } \\
\text { activities in } \\
\text { Tabanio } \\
\text { village. }\end{array}$ & $\begin{array}{l}\text { Community } \\
\text { members in } \\
\text { Tabanio village } \\
\text { demanded that } \\
\text { KJW Ltd. } \\
\text { terminated its } \\
\text { operations. }\end{array}$ & $\begin{array}{l}\text { The land } \\
\text { previously used } \\
\text { by KJW Ltd. } \\
\text { was returned to } \\
\text { the village and is } \\
\text { collectively } \\
\text { owned as a } \\
\text { common } \\
\text { property with } \\
\text { environmental } \\
\text { functions } \\
\text { restored and } \\
\text { villagers } \\
\text { acquiring user } \\
\text { rights. }\end{array}$ \\
\hline
\end{tabular}

Table 2: Contentions and conflicts in Tabanio Village, South Kalimantan 


\section{Land tenure issues and their implications at the local level}

Through the country's Basic Agrarian Law, Indonesia's coastal areas are increasingly converted into palm oil plantations and dominated by monoculture cultivation. Rife with contentions and conflicts, land politics in Indonesia heighten when communal land is appropriated for agro-development. In the New Order and the Post New Order era, dispossession has been a major issue. In 1960 the Basic Agrarian Law (BAL, Law 5/1960 on Basic Agrarian Principles ${ }^{3}$ ) replaced the Civil Code provisions on land rights across Indonesia (Neilson 2016: 251). The intention was, through registration, to transform all existing land rights into rights derived from the Basic Agrarian Law (Neilson 2016: 251). By extending the scope of state land, the Basic Agrarian Law enabled the government to allocate large areas to developers and plantation companies. The state assumed two functions: first, as a recorder of existing private rights, and second as a creator of rights that it could hand out more or less at will. The second function gave the government a key role in determining land use, through the types of rights it provided, such as the right to build or establish a plantation (Neilson: 2016: 251). The government thus promotes public policies on land use through private law:

In general, the design of 'new' institutions for land management appears to be strongly conditioned by preexisting administrative traditions, e.g. when making decisions about delegation and devolution to indigenous and community user groups, government officials behave rationally and select from a menu of choices that has emerged from wider social processes such as the adoption of western land rights system under Indonesian labels, the state right of control over land use through the Basic Agrarian Law and the promotion of public policies on land use through private law. (Neilson 2016: 252)

Article 5 of the BAL claims to support adat or common indigenous law, but indigenous communal right of avail was recognized only under strict conditions. Indigenous communities had to prove their existence, by demonstrably following traditions and adhering to indigenous institutions (Neilson 2016: 251). In the case of Tabanio, the adat institution was captured by government and company interests, which reinforced the commercialization of local land and natural resources. The right of avail could, moreover, never be used against the 'state interest', nor could it be registered. The colonial domain principle was replaced by state control, reinforcing an already dominant position in land management.

Agricultural differentiation and social and political disparity in Tabanio, to a certain extent, are shaped by these land laws. By limiting the right of avail and by granting the government the authority to create new rights, the BAL reinforced the state's position. Dispossession was no longer held at bay by indigenous law, but by limits on the amount of land a person could hold, the obligation in principle to use the land oneself, and the obligation on the state to guarantee the 'social function' of land (Bedner 2016: 71). Registration of adat laws has taken place across the country, but registration has always been costly, and many eligible communities have not done it. The BAL has had only limited success, and Indonesia continues to rely on different types of land use legitimation. The duality between registered and individual rights based on indigenous laws persists (Bedner 2016: 72). In Tabanio the actors chose bits and pieces from the country's vast yet conflicting land regulations which benefited them, while jettisoning others.

The National Land Agency (Badan Pertanahan Nasional, BPN) is a federal agency which grants land titles and land certificates to the private sector. During the 1980s and 1990s, spatial planning and the procedures for issuing land development permits were top-down and tended to reserve land for a few approved developers, resulting in the speculative trading of land. This allowed developers to purchase land from owners and communities brokered by government departments at very low prices. These days the BPN has to work with local government. The 2007 Spatial Planning Law decentralized land development and land use permit issuance to local governments, allowing greater participation in coastal spatial plans (Fay 2016: 92). The obstacles to local management of land affairs are:

\footnotetext{
${ }^{3}$ http://extwprlegs1.fao.org/docs/pdf/ins3920.pdf
} 
(i) local government lacks the capacity to effectively manage and implement land use plans and development permits,

(ii) consistent law enforcement remains a problem in the land development and spatial planning system, leading to discrepancies between land use/zoning regulations and land use permits that are issued,

(iii) government officials extract resources from agribusiness corporations and land development institutions - a form of rent-seeking where some local governments benefit from fees paid by corporations and developers for their permits, and

(iv) public participation in planning and monitoring is merely a technical and political formality, achieved by holding a few public meetings, thus communities are underrepresented and accountability to the public is quite low.

In South Kalimantan and Tabanio planning was poorly managed, the law incomplete, and there were inconsistencies in implementation. Delegated land governance led to regulatory capture, administrative seizure and insider influence by precisely those powerful interests whose behavior the laws intended to control.

\section{Discussion}

Public participation through the implementation of the principle of free, prior, and informed consent remains indispensable if conflicts are to be reduced. A system implemented from the top down on land with competing claims is bound to result in conflict. The main challenge ahead is to ensure that local communities share the benefits rather than generating windfall gains for brokers and mediators who profit from conflicts. Active engagement of NGOs is required to ensure the emergence of a more sustainable production system that supports the desire of local communities for autonomous development. Clear and accurate information about their options can help communities better assess companies' offers and this is where the NGOs can offer guidance. (Gillespie 2018: 311)

In the case of Tabanio and Ujung Batu, inequality in economic and political influence and inequality in access to knowledge and information, when combined with inadequate communication, led to conflicts and contentions. To policy makers, a development strategy should stimulate social and economic improvements based on locally available natural resources, native agricultural endowments and suitable regional environments. Hence, an agricultural development strategy at the local level should be based on an agricultural production model which can be adopted sustainably, cohesively, profitably and cost effectively by local inhabitants. But in many cases in Indonesia and in South Kalimantan, participatory agricultural development and natural resource governance is really a technical project rollout. It is not uncovering underlying causes of inequity and ecological destruction, and leading to politically inclusive development and extension practices marked by deliberation, empowerment and active citizenship as Gillespie outlines. Such processes are a middle ground between control and technical rollout by the nested power structure of the state, and grassroots political activism. Active citizenship involves community actions, governing through one's allegiance to pre-existing communities and transforming them, investing them with new values and collective identities.

Political ecologists believe that changes in the environment do not affect society in a homogenous way. Firstly, political, social and economic differences account for uneven distribution of costs and benefits (Bebbington and Batterbury 2001). Political power plays an important role in creating such inequalities. Secondly, this uneven distribution of costs and benefits inevitably reinforces or reduces existing social and economic inequalities (Ndi and Batterbury 2017), as in the case of Tabanio. Thirdly, this holds political implications in terms of the altered power relations that are produced (Bebbington and Batterbury 2001), and passive resistance and subsequent protests against the social and economic ills from oil palm expansion led to Tabanio's altered power relations. Agrawal (2008: viii) noted the emergence of environmental subjects, i.e. "...people who have come to think and act in new ways in relation to the environment." He says "...the environment constitutes for them a 
conceptual category organizing some of their thinking; it is also a domain in conscious relation to which they perform some of their actions." (2008: 219). The significance of Agrawal's concept lies in its ability to explain the shift from negligence to active membership, "state to community" and "bureaucracy to democracy" in the context of identity building and identity regulation within communities (2008: 270). In the case of Tabanio, changes in land management practices subsequent to Kintap Jaya's withdrawal led to changes in identifying with the land and its coastal resources. These resituate community groups' conceptual categories with which they organize some of their thinking with regard to land use and land management, fostering social sensibilities and ecological responsibilities.

\section{Countering extractive institutions, adverse incorporation and environmental degradation}

In this case study, poorly functioning land institutions and legal frameworks led to insecure tenure rights for villagers in accessing and utilizing common land. This allowed land markets to enter and commodify common land in Tabanio, enabled by the state. "Although the state has effectively withdrawn in the neoliberal period, informally the role of local state based actors remains pivotal to agrarian differentiation and the eclipse of customary entitlements" (Neilson 2018: 112). At the outset, the forest was kept intact, but eventually the company clandestinely started converting the forest to plant oil palm seedlings. In Tabanio those able to engage in oil palm production remained poor, or faced deeper poverty. These impoverished and marginalized community groups lost their land and their economic base. Tabanio's Alliance for Environmental Protection was a resistance group that protested at the provincial government's office. A member, Mr. ABKR, stated the following:

Apart from the village officials, almost none of the villagers participated in creating government regulations, in making land concessions to Kintap Jaya Watindo and in deciding the borderline between Tabanio and Ujung Batu. Usually only the village officials and those well known in the village participate. We also have a lot of work to do here and we don't come to things like that. A lot of the times we don't even know there are government officials coming here to make new government statutes or to enforce new decisions relating to land use and the palm oil plantation company. We find that all of a sudden the oil palm company moves in and we are not allowed to enter the land belonging to the village where we used to grow things. It makes no sense because they take our fertile and productive land, they move in on us, they do not give us anything, and if we want to work with them to take out credits from the company cooperative or to ask for their help in acquiring seed, fertilizers, mills, etcetera, we will have to pay a lot of money for it even more expensive than in other places around here.

This suggests the emergence of a narrow distribution of power, non-inclusive governance and adverse incorporation into the oil palm scheme. Despite civic movements and protests within Tabanio's village government during the 2009-2011 administration, the village and district governments were no more than a contentious debating community and a rubber stamp. Intimidation from the Regency and provincial government and community groups' lack of bureaucratic prowess led to little or no community participation in decision making processes. Hence, bureaucrats and government officials at the village, district and Regency levels along with company representatives decided on land use. Tabanio's concentration of power reinforced agricultural differentiation, inequality in access to capital, social and political disparity, marginalization of the majority and the cultural and political underpinnings for extractive social, ecological and economic institutions. Extractive political institutions concentrate power in the hands of a narrow elite. Extractive economic institutions depend on extractive political institutions for their survival (Acemoglu and Robinson 2012). The following was noted by a villager named Mr. RLDP:

The Tala Regency Head stated that the palm oil plantation company will create massive new jobs and improve local welfare, but in fact it is only a myth and it only creates poverty and desperation among villagers in Tabanio because of land grab, loss of natural resources, environmental destruction and loss of income. Regency Decree No 179 Year 2010 led to the loss of 900 ha of land 
and $70 \%$ of the White Samet forest in Tabanio village. The forest is destroyed by the company and is almost gone by now, and this also led to salt water intrusion, flooding, water pollution from the plantation's runoff and the loss of water reservoir areas because of the destruction of marshes and estuaries which function as reservoirs. Moreover, the company employed workers from outside the village and only 5 people from Tabanio are employed by the company, hence contributing very little or almost nothing to family income. If the White Samet forest and the marshes and estuaries are still present, then the villagers would still be able to utilize the flora and fauna there to provide income. But the oil palm plantation is much more attractive, promising and profitable for government elites and investors.

Extractive institutions in Tabanio include:

(i) the local land institution at the provincial, Regency and district levels which collaborate with developers, agricultural industries, the National Land Agency and local government officials for rent seeking purposes on common land,

(ii) the local cooperative in Tabanio working under the mentorship and endowment of the holding group and the government which dispossesses farmers through unfair credit schemes and their systematic alienation from fertile land, and village infrastructure (e.g. dikes and irrigation facilities), milling facilities and market access,

(iii) the Regency, district and village governments who practiced rent seeking on common land, with collusion with company representatives, corruption of donations made by Kintap Jaya, deception, manipulation and intimidation for oil palm expansion in the village,

(iv) the oil palm plantation holding group responsible for land grabbing and undermining villagers' effort to protect the social and ecological landscape,

(v) the adat or common/indigenous organization at the village level which was captured and pressured by Kintap Jaya and the local government to commercialize local land resources despite enduring conflicts and contentions, and

(vi) the military and the task force groups set up by the provincial government to restore peace and order in times of conflicts which often perpetuated violence and the criminalization of local villagers.

Whereas inclusive institutions may be good for the environment and the local economy, some people or groups will be much better off by setting up institutions that are extractive, and in Tabanio this was done by reinforcing the power of the corporation and governing through the enactment of Regency Decree No179/2010 on the borderline between Tabanio and Ujung Batu. This is exemplified by the following statement made by Ms. RSND, an executive from the local NGO:

The enactment of Regency Decree No 179 in 2010 put Tabanio at a great loss since through the above decree more or less 900 ha of land was given to Ujung Batu and was ultimately conceded for use by Kintap Jaya through the local government. This is a change from the previous border stipulated on the map which was informally consented and informally created in 1992. Before the enactment of Regency Decree No 179 Year 2010, government officials and representatives from Tabanio came to the field site in the village and ensured that the border informally created in 1992 is and will be the official border, but then all of a sudden Regency Decree No 179 Year 2010 was promulgated and forced upon the villagers in Tabanio by the provincial, Regency and village governments and representatives from Kintap Jaya without prior knowledge and consent. This piece of land had always been contested in terms of status and ownership since 1992. It seems that the private property regime, the common property regime and the public/government property regime were all attached to this piece of land, leading to open access and land grab by Kintap Jaya through government officials at all levels. 
To create more pluralistic institutions and power bases, voluntary actions by the powerful are unlikely. Forcing elites to broaden the power base was the catalyst in this case. The social dissonance and environmental destruction caused by oil palm expansion led to community resistance, the emergence of new identities that are socially and ecologically responsive, and the advent of plurality in Tabanio's power bases. Once this occurred, diversified power bases and the emergence of platforms for mobilization, change and inclusion has made it harder for others to usurp power in future. Inclusive institutions, in turn, create a more equitable distribution of resources (Acemoglu and Robinson 2012: 84-87) and in the case of Tabanio, also led to ecological sensibility and environmental protection.

Particularly important was the fact that community resistance caught the attention and involvement of higher level authorities from the Province and the Regency, with political figures from Indonesia's main political parties in the House of Representatives harboring to protect the interests of the villagers. This brokering by higher level authorities and institutions led to:

(i) judicial involvements,

(ii) judicial reviews by local courts at the provincial and Regency levels to promote new legal interpretations of Tabanio's land use pattern and land management,

(iii) the transformation of the case into judicial doctrines and legal procedures for proper consultation and rights of veto by community groups in order to safeguard Tabanio's coastal areas,

(iv) binding Memorandum of Understandings between government departments, Kintap Jaya and community user groups to end the company's activities in Tabanio and to restore Tabanio's coastal zone into collectively managed coastal areas,

(v) reinforcement of the original border between Tabanio and Ujung Batu which was informally promulgated in 1992, and

(vi) the reinforcement and strengthening of Tabanio's communal (adat) laws and communal (adat) institutions for determining and negotiating access and utilization of local land and natural resources.

These changes led to plural meanings and attachments to Tabanio's land resources beyond that of commercialization and regulatory measures induced through government propagandas. Social and cultural pluralism influences groups and individuals in multidimensional ways: they alter the barriers and enablers for collaborative action and collective natural resource protection, and these barriers and enablers are always susceptible to negotiations and change, leading to the potential for reflection and social and ecological sensibilities to emerge and endure (Meilasari-Sugiana 2012: 198).

Just as power and influence are not inter-changeable, power and authority differ considerably (Etzioni 1968: 353). Authority is defined as legitimate power, or "...power that is used in accord with the subject's values and under conditions viewed as proper" (Etzioni 1968: 353). The case of Tabanio suggests that the various forms of power eventually tend to slant compliance in their own direction (Etzioni 1968: 353). Nonetheless, as suggested by Etzioni and portrayed in Tabanio, due to a neutralization effect, power can be lost. This contributes to the contingent emergence and dissipation of multiple management regimes in local natural resource governance landscapes. Moreover, "power is always relative to the authority which supplies its justification and legitimacy across time and space" (Etzioni 1968: 355). Community groups in Tabanio are highly aware that in the absence of deliberative participation and genuine devolution of responsibility, the devolution of power to local communities and their leaders after 2011 could have led to nested relations of power, reinstating local elites and their extractive socio-political institutions. Therefore, there is a continuing tension in the use of power by community members, along with the need to involve higher level authority to induce change. Perceived urgency of change has slowed since the restitution of land. Etzioni (1968: 364) noted that "...the more rapid the transformation of a societal structure, the less need there is for order enforcing organization and the more slow a transformation, the greater the need for such organization whereby power and force are involved." Groups and individuals still need to reflect on their decisions and actions and be cognizant of the need to protect the social environment and local coastal 
resources. An institutionalization of commitment depends on reflection among villagers who recognize and validate each other's existence and efforts to protect nature and social relations. At the heart of this is the need to engage resource users through identity, imagination and social reciprocity in collective natural resource protection.

Land reform and changes in livelihood require individual willingness and social structural forces: hence there is the need to understand how structure and agency mutually interact, in particular contexts. Following Etzioni (1968: 346), the Tabanio case suggests that "an application of power influences and changes the actor's situation, but not the consciousness over an individual's preferences." Systematization of differences among user groups is omnipresent, and in Tabanio, disconnections and limitations in the application of power led to contentious and contingent restructuring of the social and ecological landscape.

The study suggests that facilitating responsiveness and participation for protecting common resources requires creating a new social and political space that provides a sense of importance and identity to community user groups (Potter 2018). At the heart of this is the need to engage resource users through identity, imagination and social reciprocity in collective land and natural resource protection and encapsulate them within customary (adat) laws and institutions. Active engagement of this nature can lead to the creation of space for reflection and change, therefore stimulating groups and individuals to be more responsive in assuming responsibility for protecting the social and ecological landscape and avoiding its capture. A local sense of importance, recognition and obligation to act for the collective good can motivate people to perform extraordinary actions. Facilitating participation and inclusion in natural resource protection requires extending beyond utilitarianism and into the social, political and psychological. Natural resource governance requires understanding groups and individuals and the patterns of exchange underlying their everyday social practice. This shapes the structure of community life within a particular locality. This case in South Kalimantan suggests that this structure and pattern, when 'successfully altered' to incorporate the concept of social and ecological responsibility, may become the basis for imparting 'agendas' related to equity and sustainability. Consequently, there is a need to incorporate agency (i.e. willed action), social structural forces and their interactions when promoting devolution in land and natural resource governance.

\section{Lessons learned in facilitating ecologically sustainable land reforms}

Indonesia's growth-oriented economy, agro-industrial intensification, contrived devolution of natural resource governance and inconsistencies in land regulations have all led to the marginalization and dispossession of low income, indigenous communities in rural areas. The role of policy makers, extension officers and community members is to remove impediments to change by recognizing diversity and untapped potential (Harmon 1986). The Government must promote a non-capitalist definition of efficiency in land governance while encouraging local resource management, social and ecological resilience and community welfare. The limits of commensurability needs to be considered and integrated into policy making at the sub-national level, fostering the protection of ecosystem services and the communities which gravely depend on them. The government thus needs "...to take seriously the recent surge of voices advocating degrowth, relocalization, post-capitalism, and the imperative of collectively changing the rules of the game" (Hornborg 2017: 626). Decentralization and devolution has to take into account the different forms of perception underlying community involvement in natural resource governance and how these encourage groups and individuals to evolve behavior which is commensurate with their responsibilities to protect the social and ecological landscapes. Building from the case study, the following are required to instill the equitable and sustainable governance of land resources:

(i) Insulation from the intrusion and commercialization of common land by external institutions through consistently enforced legislation, advocacy and protection by government agencies and NGOs, and accountability of agro-industrial holding groups,

(ii) proper consultation and informed consent from villagers for access and tenure rights to common land,

(iii) rights of veto by community user groups in the absence of majority consensus,

(iv) building independently governed adat institutions at the village and district level for protecting collective interests, 
(v) consistencies in land regulations, land use, and land enforcement mechanisms,

(vi) brokering by higher level authorities and institutions in times of contention, and lastly

(vii) binding MoUs and judiciary involvement to promote new legal interpretations and turn cases into judicial doctrines.

It is within these contexts that politically cohesive, ecologically sensible and socially equitable land reforms can be achieved. The way the villagers perceive the fairness of a decision-making process is what leads them to comply, withdraw or embark on immediate confrontation and conflict. In the case of Tabanio, being able to voice concerns for their welfare has a positive effect on the villagers' perception of fairness and their reaction to a decision. NGOs can better support local communities by improving the transparency, comprehensibility and accountability of schemes offered by oil palm companies, who have in turn to communicate honesty with villagers. The community groups' negotiation skills can be greatly improved through government and NGO programs, leading to better positioning with commercial operations.

The main challenge revealed in this article is to ensure that local communities share the benefits rather than generating gains for commercial operations, and the brokers and mediators who profit from conflict. Clear and accurate information about their options can help communities better assess companies' offers. In the case of Tabanio, it appears citizenship and inclusion became resituated in 'community', transforming it, and giving it new values.

\section{References}

Acemoglu, D. and J.A. Robinson. 2012. Why nations fail: the origins of power, prosperity and poverty. New York: Crown.

Agrawal, A. 2008. Environmentality: technologies of government and the making of environmental subjects. Oxford: Oxford University Press.

Bappeda-Sulsel. 1998. Rencana strategis pengelolaan pesisir dan laut. Sulawesi Selatan: Badan Perencanaan Pembangunan Daerah Sulawesi Selatan.

Bebbington, A.J. 2006. Local capacity, village governance and the political economy of rural development in Indonesia. World Development 34(11): 1958-1976.

Bebbington, A.J. and S.P.J. Batterbury. 2001. Transnational livelihoods and landscapes: political ecologies of globalization. Ecumene 8(4): 369-380.

Bedner, A. 2018. Indonesian land law: integration at last? And for whom? In McCarthy, J.F. and K. Robinson (eds.) Land and development in Indonesia: searching for the people's sovereignty. Singapore: ISEAS Press. Pp. 63-92.

BPS. 2000. Statistik Indonesia 1970-2000. February 16, 2004. http:/www.bps.go.id/sector/population.

Cramb, R. 2018. The political economy of large-scale oil palm development in Sarawak. In Cramb, R and J.F. McCarthy (eds.). The oil palm complex: smallholders, agribusiness and the state in Indonesia and Malaysia. Singapore: NUS Press. Pp. 189-246.

El Swaify, S. 1983. Soil erosion by water. In R. Carpenter (ed.) Natural systems for development. London: MacMillan. Pp. 99-159.

Etzioni, A. (ed.) 1968. The active society: a theory of societal and political processes. London: Collier-McMillan.

Fay, C. 2018. Emerging options for the recognition and protection of indigenous community rights in Indonesia. In McCarthy, J.F. and K. Robinson (eds.) Land and development in Indonesia: searching for the people's sovereignty. Singapore: ISEAS Press. Pp. 91-112.

Fetterman, D. 1989. Ethnography: step by step. Thousand Oaks: Sage.

Gillespie, P. 2018. People, participation, power: the upstream complexity of Indonesian oil palm plantation. In Cramb, R. and J.F. McCarthy (eds.). The oil palm complex: smallholders, agribusiness and the state in Indonesia and Malaysia. Singapore: NUS Press. Pp. 301-326.

Harmon, M. 1986. Organization theory for public administration. Boston: Little Brown and Company. 
Hornborg, A. 2017. How to turn an ocean liner: a proposal for voluntary degrowth by redesigning money for sustainability, justice and resilience. Journal of Political Ecology 24(1): 623-632.

Levang, P., W.F. Riva and M.G. Orth. 2018. Oil palm plantations and conflicts in Indonesia: evidence from West Kalimantan. In Cramb, R. and J.F. McCarthy (eds.) The oil palm complex: smallholders, agribusiness and the state in Indonesia and Malaysia. Singapore: NUS Press. Pp. 283-300.

Li, T.M. 2018. Situating transmigration in Indonesia's oil palm labor regime. In Cramb, R and J.F. McCarthy (eds.) The oil palm complex: smallholders, agribusiness and the state in Indonesia and Malaysia. Singapore: NUS Press. Pp. 354-376.

Lynch, O.J. and E. Harwell. 2002. Sumberdaya milik siapa? siapa penguasa barang publik? Jakarta: Studio Kendil.

Meilasari-Sugiana, A. 2012. Collective action and ecological sensibility for sustainable mangrove governance in Indonesia: challenges and opportunities. Journal of Political Ecology 19: 184-201.

Ndi, F.A. and S.P.J. Batterbury. 2017. Land grabbing and the axis of political conflicts: insights from Southwest Cameroon. Africa Spectrum 121(1): 33-63.

Neilson, J. 2018. Agrarian transformations and land reform in Indonesia. In McCarthy, J.F. and K. Robinson (eds.) Land and development in Indonesia: searching for the people's sovereignty. Singapore: ISEAS Press. Pp. 245-264.

Neuwman, L. 2003. Social research methods: qualitative and quantitative methods. Boston: Pearson Education.

Potter, L. 2018. How can the people's sovereignty be achieved in the oil palm sector? Is the plantation model shifting in favor of smallholders? In McCarthy, J.F. and K. Robinson (eds.) Land and development in Indonesia: searching for the people's sovereignty. Singapore: ISEAS Press. Pp. 315-342.

Thorburn, C. 2001. Regime change prospects for community based resource management in post new order Indonesia. IASCP Inaugural Pacific Regional Meeting, Brisbane, Australia. 